\title{
Passive Corrosion Protection of Al-Zn-Mg alloy in Seawater
}

\section{Pasivna zaštita od korozije legure Al-Zn-Mg izložene morskoj vodi}

\author{
Wojciech Jurczak \\ Faculty of Mechanical and Electrical \\ Engineering \\ Polish Naval Academy \\ e-mail:W.Jurczak@amw.gdynia.pl
}

\section{Summary}

In the article the chosen problems connected with corrosion of the maritime construction materials with particular consideration of the passive anticorrosion protection using high strength aluminum alloy and its welded joints were presented. Also currently used methods of anticorrosion protection of maritime constructions with use of aluminium and its alloys in form of protective coatings and sacrificial anodes were described. The first part of the article presents the corrosion resistance of the basic material of the tested alloys series 7xxx (Al-Zn-Mg alloys). In the further part of the article the results of the own researches concerning the passive protection of the $\mathrm{Al}-\mathrm{Zn}-\mathrm{Mg}$ alloy and its joints of the $\mathrm{AlZn} 5 \mathrm{Mg} 2 \mathrm{CrZr}$ alloy (mark $7020 \mathrm{M}$ ) with the systems of protective paints and sacrificial anode cathodic protection were presented. $7020 \mathrm{M}$ alloy is a modification of the chemical composition of the alloy 7020 (AIZn4,5Mg1 alloy). In the 7020M alloy the increase of corrosion resistance and strength was obtained by increasing the total $\mathrm{Zn}+\mathrm{Mg}>7 \%$ and adding $\mathrm{Cr}$ and $\mathrm{Zr}$. The effectiveness of the anticorrosion protection has been determined by a comparison of the mechanical properties deterioration of the protected and unprotected welded joints that were set under the influence of stress and artificial seawater. The welding process is a type of heat treatment consisting of: heating, supersaturation and cooling at room temperature. This type of heat treatment called natural is the most susceptible to corrosion in seawater. Each type of welded joint means increased corrosion susceptibility. The system of epoxy paints provides more efficient protection from the effects of stress corrosion for the welded joints of $7020 \mathrm{M}$ alloy than the system of polyvinyl paints. Electrochemical potential of $7020 \mathrm{M}$ alloy determined on microstructure depends on chemical composition and heat treatment. This group of materials, which are characterized by the electrochemical potential lower than $-1000 \mathrm{mV}$ vs. SCE, can be used in sacrificial anodes for the tested alloy.

\section{Sažetak}

U radu se prikazuju izdvojeni problemi koji se tiču korozije materijala u brodskim konstrukcijama, sposebnim osvrtom na pasivnu zaštitu od korozije uporabom visokootpornih legura aluminija i zavarenih spojeva. Također se opisuju metode zaštite od korozije koje se trenutno koriste uporabom aluminija i njegovih legura u obliku zaštitnih premaza i trošenja anoda. U prvome dijelu rada opisuje se otpornost osnovnih materijala testiranih serija legura $7 x x x$ (legure Al-Zn-Mg) na koroziju. U nastavku rada izlažu se rezultati autorova istraživanja pasivne zaštite legure Al-Zn-Mg i spojeva legure AlZn5Mg2CrZr (oznaka 7020M) sustavima zaštitnih boja i katodne zaštite trošenjem anode. Legura 7020M predstavlja modifikaciju kemijskog sastava legure 7020 (AlZn4,5Mg1 legure). U leguri 7020M povećanje otpornosti na koroziju i čvrstoća materijala postignuti su povećanjem ukupnog $Z n+M g>7 \%$ i dodavanjem $\mathrm{Cr}$ i Zr. Učinkovitost zaštite od korozije utvrđuje se usporedbom mehaničkih svojstava propadanja zaštićenih i nezaštićenih zavarenih spojeva koji su izloženi naprezanju i imitaciji morske vode. Postupak zavarivanja vrsta je toplinske obrade koja se sastoji od: zagrijavanja, supersaturacije i hlađenja na sobnoj temperaturi. Ovaj tip toplinske obrade, koji se naziva prirodnim, najosjetljiviji je na koroziju u morskoj vodi. Svaka vrsta zavarenog spoja znači veću izloženost koroziji. Sustav epoksi boja pruža učinkovitiju zaštitu od učinaka korozije pri naprezanju zavarenih spojeva legure 7020M nego sustav polivinil boja. Elektrokemijski potencijal mikrostrukture legure 7020M ovisi o kemijskom sastavu i toplinskoj obradi. Ova skupina materijala, koje karakterizira elektrokemijski potencijal niži od -1000mV nasuprot SCE, može se koristiti u trošenju anode za testiranu leguru.
DOI 10.17818/NM/2019/3.2 UDK 620.19:669.715

Preliminary communication / Prethodno priopćenje Paper accepted / Rukopis primljen: 24. 6. 2019.

\author{
KEY WORDS \\ aluminium alloy \\ welded joints \\ sacrificial anode cathodic protection \\ coatings
}

\section{INTRODUCTION / Uvod}

Aluminum is an important material due to its lower density, potentially high strength to weight ratio in mechanical strength, and cyclic flexural performance, depending on alloying elements and microstructure. While alloying yields improved mechanical performance, it can also result in sensitivity to corrosion.

Corrosion is a continuous, natural, chemical or electrochemical 
influence between the surfaces of the structural materials and the surrounding environment. In effect of this influence a gradual destruction (oxidation) of the metals and their alloys and also of the non-metallic elements (concrete, plastics) takes place and decreases their operational properties by arising material decrements, cracks, corrosive brittleness that advances inside the material. Each kind of corrosion causes the material decrement and threat for the construction safety and maintenance.

According to the statistics, about $30 \%$ of the manufactured metals are taken out from service because of corrosion. The corrosion cost amounts 276 billion dollars per year [1].

In comparison to the corrosion rate in the air, in the humid environment the corrosion takes place much more rapidly. Metals influenced by water and oxygen are corroding much more rapidly and material decrement level becomes high. It might be expected that the rate of the oxidation in the air is connected with the driving forces of the corrosion in the humid environment. Because of the complexity of the influences of the different agents on the corrosion process with participation of water, the corrosion rate of many metals is changing in a wide range, what depends on the water chemical composition (level of salinity and $\mathrm{pH}$ ), water temperature and velocity of the flow around a body (oxidation level) [2].

Maritime constructions "working" in a maritime environment are exposed to the simultaneous influence of the operational load (constant and variable) and the action of water and maritime atmosphere, what causes an intensive corrosion and hasten technical wear of all maritime objects.

The weakest part of each construction, concerning both mechanical properties and corrosion resistance, is the welded joint.

More often during the designing of the constructions in a shipbuilding industry the aluminium alloys are used. Alloys from the Al-Zn-Mg configuration, including the analysed alloy, have the best strength properties among aluminium alloys used in shipbuilding, including their welded joints. Unfortunately, they have an inclination for the stress corrosion in seawater. An important indicator that determines the inclination of the alloys from this configuration for the stress corrosion is the total amount of $\mathrm{Zn+Mg}$ [3]. Increased amount of $\mathrm{Zn+Mg}$ makes the alloys more susceptible for the stress corrosion. Addition of $\mathrm{Cr}$ and $\mathrm{Zr}$ increases the resistance to the stress corrosion. Similarly, the chemical composition of the binder metal influences the corrosion resistance of the welded joints. Additional parameter that influences the corrosion resistance of the welded joints is the width of the heat-affected zone (HAZ), which depends mostly on the welding conditions (chosen method, parameters, and thickness of the welded metal plates).

The elements of the naval constructions made of aluminium alloys are connected by welding. Rivet joints are just for joining aluminum alloy with steel e.g. aluminum structure with steel coll. In effect of a welding process (used methods are MIG and TIG) a HAZ is forming in a welded joint, which dimensions are relatively large (3-5 times bigger than HAZ in welded joints of steel) and it is the weakest area, concerning the corrosion resistance [4]. Welding heat causes structural changes in $\mathrm{HAZ}$, which decreases their corrosion resistance and strength properties (by 30-50\%).

Corrosion in seawater is electrochemical corrosion in which value of electrochemical potential determines corrosion inclination. The lower the electrochemical potential, the higher the corrosion inclination.

\subsection{Passive methods of anticorrosion protection of} the construction materials with use of aluminium and its alloys / Pasivne metode zaštite od korozije konstrukcijskih materijala uz uporabu aluminija $i$ njegovih legura

Passive protection depends not only on the isolation of the constructional materials from the oxygen included in water or air (for example by using the protective coatings) but also on usage of the sacrificial anode materials or inhibitors (salts of tin, arsenic, nickel, magnesium or starch, glue, protein).

Aluminium and its alloys are used with passive protection in form of components of the non-metallic coatings and sacrificial anodes for cathodic protection.

\section{PASSIVE PROTECTION - NON-METALLIC PROTECTIVE COATINGS / Pasivna zaštita - zaštitni premazi od nemetala}

Systems of protective paints must be properly selected for the protected material. Radically different coatings are used in order to protect metallic and non-metallic materials, but the common task of all the coatings for both kinds of material is to isolate their surface from the oxygen and the natural corrosive factors. Organic protective coatings are commonly used in protection of the metallic structures. They include: paints, lacquers, rubberor plastics- made linings. They protect engineering structures in various conditions, both in atmospheric corrosion conditions and also in the most aggressive conditions of the industrial installations, for example in the desulphurization systems.

Protective properties of the coatings are connected with many mechanisms, such as: a) barrier (isolation of the base from the environment with corrosive power), b) adhesive (good adhesion of the coating prevents the underfilm corrosion) c) electrochemical (presence of the active pigments in the coatings decreases the rate of the corrosive reaction).

Usage of the protective coatings for metals is the cheapest way of protection of the construction materials, which are commonly non-precious metals, and also gives a possibility for optimal utilization of the technical properties of these metals. The aim of usage of the known methods of anticorrosive active and passive protection in engineering is to gain full control of the corrosion processes and to provide safety [7].

\subsection{Own research / Istraživanje}

\subsubsection{Experimental study / Eksperimentalna studija}

In Table 1 showing mechanical properties (without coatings) of particular ship Al-Zn-Mg alloys are depicted and their resistance to particular types of corrosion are determined by average percentage decrease of mechanical $K_{R m}$ (formula 1) and plastic $\mathrm{K}_{\mathrm{A5}}$ (formula 2) properties under the influence of sea atmosphere.

Results of the examination of the stress corrosion resistance of the examined welded joints without protective coatings were determined by the coefficients $\mathrm{K}_{\mathrm{Rm}}$ and $\mathrm{K}_{\mathrm{A} 5}$.

$$
\begin{aligned}
\mathrm{K}_{\mathrm{R}_{\mathrm{m}}} & =\frac{1}{\mathrm{n}} \Sigma \frac{\mathrm{R}_{\mathrm{mo}}-\mathrm{R}_{\mathrm{mk}}}{\mathrm{R}_{\mathrm{mo}}} 100 \% \\
\mathrm{~K}_{\mathrm{A}_{5}} & =\frac{1}{\mathrm{n}} \Sigma \frac{\mathrm{A}_{0}-\mathrm{A}_{\mathrm{k}}}{\mathrm{A}_{0}} 100 \%
\end{aligned}
$$

$R_{m o}$ - tensile strength before the exposure; 
$\mathrm{R}_{\mathrm{mk}}$ - tensile strength after the exposure;

$\mathrm{n}$ - number of samples;

$A_{0}$ - plastic extension of the material before the exposure;

$A_{k}$ - plastic extension of the material after the exposure;

$\mathrm{K}_{\mathrm{Rm}}$ - the mean percentage reduction of the tensile strength after the corrosion exposure;

$\mathrm{K}_{\mathrm{A} 5}$ - the mean percentage of plastic elongation of the test samples, after the corrosion exposure.

Investigation of resistance to neutral salt spray (NSS) in accordance with the PN-EN ISO 9227 (ASTM B 117, DIN 50907) standard recommends the following intervals between inspections of the samples subjected to salt spray impact: 2 , $6,24,48,96,168,240,480,720$ and 1000 hours. Reported tests lasted 1000 hours; salt spray exposure took 12 hours, for the next 12 hours the samples were dried. Duration of salt spray was 30 minutes followed by 30-minute break.

\subsection{Results and discussion / Rezultati i rasprava}

The research results given in Table 1 show the corrosive resistance of $7 x x x$ alloys. However, strength properties of $7 x x x$ are better than strength properties of Al-Mg. As a safety parameter, the ship construction engineer assumes the strength and probability of changes of exploiting properties in a result of heat treatment. It determines the usage of 7xxx alloys and corrosive susceptibility is minimalized by the use of protective paints.

Modification with $\mathrm{Cr}$ and $\mathrm{Zn}$ of the alloy 7020 for $\mathrm{Zn}+\mathrm{Mg}>7 \%(7020 \mathrm{M})$ resulted in an increase in stress properties and comparable corrosion resistance. Corrosion resistance of 7xxx series alloy can be improved using selected heat treatment $\mathrm{T}_{622}$ (artificially aged after saturation), in which cooling after saturation was accomplished in hot water $\left(80^{\circ} \mathrm{C}\right)$. For investigated alloys the additional anticorrosion protection measures have to be applied.

Recently, the "Polifarb-Oliwa" company designed new paint for aluminium marine constructions. These paint systems are based on: polyvinyl paints /marked as $\mathrm{P} / \mathrm{-} 1$ layer of anticorrosive vinyl paint 7729-064-XXO + 2 layers of anticorrosive thixotropic vinyl paint 7729-272-XXO + 1-2 layers of antifouling vinyl paint VOP7753-074-XXO - total thickness of a system 170-250 [ $\mu \mathrm{m}]$; epoxy paints /marked as E/ - 1 layer of EPIWELD zinc 7423014-950 + 2 layers of EPINOX 887423-088-XXO + 1-2 layers of antifouling paint VOP 7753-074-XX antifouling + 1-2 layers of self-polishing paint VSE 7753-070-250 - total thickness of a system 210-400 [ $\mu \mathrm{m}]$.

An example from the own researches concerning the usage of the protective paints for protection of the welded joints of the Al-Zn-Mg alloys is shown in Figure 1. In this picture the effectiveness of protection provided by the multilayer epoxy $(E)$ and polyvinyl $(P)$ coatings for the welded joints of the $7020 \mathrm{M}$ constructional alloy is presented. Average percentage decrease in the endurance $\left(\mathrm{K}_{\mathrm{Rm}}\right)$ and plastic $\left(\mathrm{K}_{\mathrm{AS}}\right)$ properties in effect of the influence of the stress-corrosion in standard conditions is much lower for the epoxy paints than for the polyvinyl paints.

Results of the researches prove that all welded naval constructions made of the Al-Zn-Mg alloys configuration should be covered with paint systems (epoxy paints for best effects) their stress corrosion resistance increases strongly, even when corrosion susceptible filler metal was used.

According to the daily observations of the samples covered with protective paints and influenced by $3 \%$ solution of $\mathrm{NaCl}$ and tensile stress, the process of corrosion is divided into two stages:

after about 1500 hours of stress corrosion exposure the protective paint starts to tarnish and also the blisters show up on the surface of sample. Number of blisters depends on a type of used paint. A blister is a place where paint loses adhesion to protected surface.

after 2500 hours first cracks of protective coatings show on the edges of the sample, followed by an aggressive corrosive attack on the heat-affected zone of the welded joint. In effect, the mechanical properties of the welded joints are reduced.

According to deeper observation of the remaining samples that have been exposed, the adhesion of the paint to the protected surfaces is good. It leads to a conclusion, that protective paint systems, that were used, increase the corrosion resistance of maritime environment to a satisfactory level. On the edges of the construction applied painting should be made with particular care. In zones there is the greatest probability of corrosive attack, due to thinner layer of protective paint at the construction edges.

The level of decrease of the mechanical properties of the welded joints after their exposure to the stress corrosion in comparison with their mechanical properties before the exposure was shown in Figure 1. Higher percentage of $\mathrm{Zn}+$

Table 1 Mechanical properties and corrosion resistance of Al-Zn-Mg alloys in heat treatment which are the most resistant to corrosion in the sea environment

Tablica 1. Mehanička svojstva i otpornost na koroziju legura Al-Zn-Mg u toplinskoj obradi, koje su najotpornije na koroziju u morskoj vodi

\begin{tabular}{|c|c|c|c|c|c|c|c|}
\hline \multirow{5}{*}{$\begin{array}{l}\text { Alloys } \\
\text { in the state }\end{array}$} & \multirow{3}{*}{\multicolumn{3}{|c|}{$\begin{array}{l}\text { Static mechanical properties } \\
\text { for } 10^{-3} \mathrm{~s}^{-1}\end{array}$}} & \multicolumn{4}{|c|}{ Corrosion resistance } \\
\hline & & & & \multirow{2}{*}{\multicolumn{2}{|c|}{$\begin{array}{l}\text { in the state } \\
\text { corrosion in the salt spray } \\
\text { chamber for } t=1000 \mathrm{~h}\end{array}$}} & \multicolumn{2}{|c|}{ in the sea water } \\
\hline & & & & & & $\begin{array}{r}\text { stress C } \\
\text { and stret }\end{array}$ & $\begin{array}{l}=1500 \mathrm{~h} \\
=0,8 \mathrm{R}_{0,2}\end{array}$ \\
\hline & $\mathrm{R}_{\mathrm{m}}$ & $\mathrm{R}_{0,2}$ & $\mathrm{~A}_{5}$ & $\mathrm{~K}_{\mathrm{Rm}}$ & $\mathrm{K}_{\mathrm{A} 5}$ & $\mathrm{~K}_{\mathrm{Rm}}$ & $\mathrm{K}_{\mathrm{A} 5}$ \\
\hline & $\mathrm{MPa}$ & $\mathrm{MPa}$ & $\%$ & $\%$ & $\%$ & $\%$ & $\%$ \\
\hline $\begin{array}{l}7020 \mathrm{MT}_{622}^{*} \\
\text { AlZn5Mg2CrZr }^{*}\end{array}$ & 443 & 397 & 9,8 & 4,7 & 23 & 5,2 & 30 \\
\hline $\begin{array}{l}7020 \mathrm{~T}_{622}^{*} \\
\text { AlZn5Mg1 }^{*}\end{array}$ & 372 & 317 & 16 & 4,4 & 30 & 8,7 & 38 \\
\hline
\end{tabular}

* heat treatment of $7 x x x$ alloys $-\mathrm{T}_{622}$ - super saturation and time $-450^{\circ} \mathrm{C} / 1.5 \mathrm{~h}\left(430^{\circ} \mathrm{C} / 45^{\prime}\right)$, cooling in the heat water $80^{\circ} \mathrm{C}$ and ageing type: $20^{\circ} \mathrm{C} / 6$ days + artificial ageing: $95^{\circ} \mathrm{C} / 15 \mathrm{~h}+150^{\circ} \mathrm{C} / 10 \mathrm{~h}[7]$. 

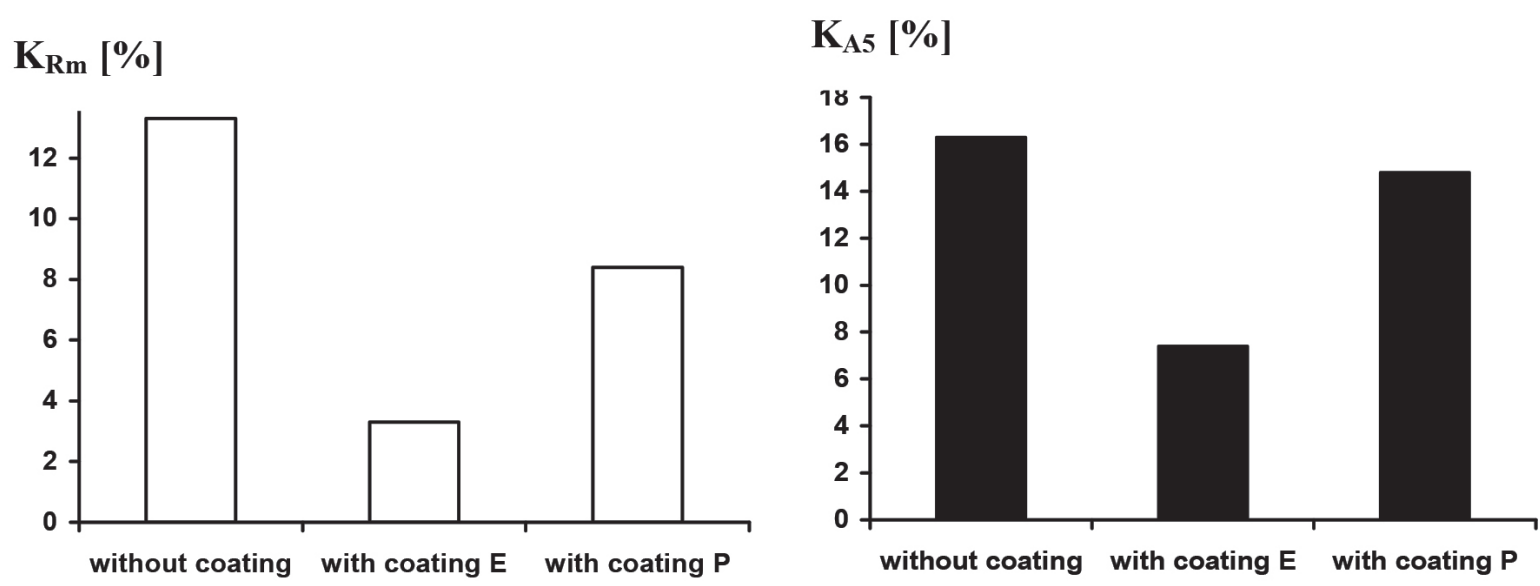

Figure 1 Comparison of the $\mathrm{K}_{\mathrm{A} 5}$ and $\mathrm{K}_{\mathrm{Rm}}$ coefficients of the welded joints $7020 \mathrm{M}$ alloy, protected (with the systems of protective paints), and non-protected, exposure for 1500 hours at $s=0,8 R_{0,2}$. Welded joints made with $T I G$ method, automatically, used filler metal was SPA20

Slika 1. Usporedba $K_{A 5}$ and $K_{R m}$ koeficijenata zavarenih spojeva legure 7020M, zaštićenih (sustavom zaštitnih boja) i nezaštićenih, izlaganje 1500 sati pri $\sigma=0,8 R_{0,2}$ : Zavareni spojevi napravljeni TIG metodom, automatski, metal za popunu koji se koristi - SPA20

$\mathrm{Mg}$ in heat 507 caused reduction of stress corrosion resistance of the welded joints of 7020M alloy. Exposure of the welded joints of the examined alloy to corrosion reduced the plastic properties by about $30 \%$ and the mechanical properties by about $20 \%$.

Usage of epoxy paints provides better protection for the maritime aluminium alloys from the corrosive influence of the maritime environment than usage of the polyvinyl paints.

Protective paints increase the level of stress corrosion resistance of the welded joints. This is confirmed by lower values of $\mathrm{K}_{\mathrm{Rm}}$ and $\mathrm{K}_{\mathrm{AS}}$ increasing the stress corrosion durability, especially for the samples protected with epoxy paints.

According to the results of the $1^{\text {st }}$ series of researches, the compared values of $\mathrm{K}_{\mathrm{A} 5}$ and $\mathrm{K}_{\mathrm{Rm}}$ for the examined samples of welded joints show (Fig.1) that the effectiveness of protection of two paint systems used is good. Epoxy paint provides better protection in comparison with the polyvinyl paint. During the 1500 hours of test none of the examined samples cracked and the reduction of mechanical properties at level of 3,5\% is low in comparison with strength of the samples without protective coating. Polyvinyl paint system shows worse protective properties - reduction of mechanical properties of the samples at $8,4 \%$ was caused by porosity of the coatings, lower adhesion to the surfaces and faster cracking of the coatings. $2^{\text {nd }}$ series of investigation confirmed lower effectiveness of that type of coatings. They tarnish and crack in a shorter time, what was causing cracking of 2 out of 5 samples, and the reduction of mechanical properties of the remaining samples was at $25 \%$. Epoxy paint system provided better corrosion protection, simultaneously reducing the strength of examined welded joints by $23 \%$, at only one sample cracked during the test.

\section{PASSIVE PROTECTION - SACRIFICIAL ANODE CATHODIC PROTECTION, LITERATURE REVIEW / Pasivna zaštita - katodna zaštita trošenjem anode, pregled literature}

Sacrificial anode cathodic protection (often called a sacrificial protection) is based on metallic connection of the protected constructional material with a sacrificial anode- a material with lower electrochemical potential. This type of anticorrosive protection enables a visual evaluation of the effectiveness of the protection system as a function of sacrificial anode mass decrement. The sacrificial anode materials in a shipbuilding are mainly $\mathrm{Zn}$ - and $\mathrm{Mg}$, used simultaneously for protection of aluminium and steel.

Sacrificial anodes made of magnesium alloy are used for anticorrosive protection of the vessels sailing in low salinity waters, like river waters, and their properties, like potential and real capacitance, guarantees lifetime within the range from 6 to 20 months.

Anodes made of zinc alloy (99,9\% pure zinc), of large specific gravity, are used in the underwater part of a hull, near the rudder, propellers, fairwaters and such.

Sacrificial anodes made of aluminium alloy have superiority over magnesium and zinc alloy anodes in respect of low cost, long life, high energy capability and light weight. This type of anode is ideal not only for the protection of weight limited structures such as submarines weapon packages but also for all types of structures including offshore platforms. The compositions used in commercial scale generally contain 2 to $5 \%$ zinc and one of the elements such as mercury, tin and indium as an activator. Dow Chemical Company [9] developed an alloy (Al-Zn-Hg) for the first time with mercury as an activator. This anode had shown a current efficiency in sea water exceeding $90 \%$ and current capacity of 2750 A-hr/kg. This alloy became popular soon after this investigation and marketed under the trade name "Galvanum". However, mercury is an environmentally controversial material and some aluminium anode users prefer not to use anodes containing mercury. This aspect made Cathodic Protection Engineers find an alternative to mercury and successfully developed some anodes with indium, bismuth, tin etc. as activators. Based on the activator elements, the aluminium alloy anodes can be subdivided into three types:

- Tin activated aluminium alloy anodes developed by Keir [10] have been in use for protection of ship's hull. Its composition is (AI $+5 \% Z n+0,12 \% S n)$. The reported anode efficiency is $70 \%$. The effectiveness of tin is attributed to reduced ionic resistance of oxide films on Al-Sn alloys. However, these anodes require controlled heat treatment for their performance and better efficiency and as such are not cost effective. Gurappa [11] successfully avoided the costly heat treatment process by the controlled addition of small amount of bismuth to (Al $+5 \% Z n+0,25 \% S n)$. 
Table 2 illustrates the effect of bismuth in improving the polarization behaviour of basic composition (Al $+5 \% \mathrm{Zn}+$ $0,25 \% \mathrm{Sn}$ ). Here bismuth helps in expanding the aluminium matrix and thereby increases the tin solubility in aluminium which is the reason for enhanced anode efficiency comparable to that of heat treated anodes.

Table 2 Characteristics of tin activated aluminium alloy anodes [12]

Tablica 2. Karakteristike anoda legure aluminija aktiviranih kositrom [12]

\begin{tabular}{|c|l|c|c|}
\hline No. & \multicolumn{1}{|c|}{ Composition } & $\begin{array}{c}\text { Anode } \\
\text { capacity } \\
\text { A-h/Kg }\end{array}$ & $\begin{array}{c}\text { Closed Circuit } \\
\text { Potential [V] } \\
\text { Ag/AgCl }\end{array}$ \\
\hline 1. & $\mathrm{Al}+5 \% \mathrm{Zn}+0,25 \% \mathrm{Sn}$ & 2052 & $-0,998$ \\
\hline 2. & $\mathrm{Al}+5 \% \mathrm{Zn}+0,25 \% \mathrm{Sn}+0,1 \% \mathrm{Bi}$ & 2139 & $-1,002$ \\
\hline 3. & $\mathrm{Al}+5 \% \mathrm{Zn}+0,25 \% \mathrm{Sn}+0,2 \% \mathrm{Bi}$ & 2197 & $-1,007$ \\
\hline 4. & $\mathrm{Al}+5 \% \mathrm{Zn}+0,25 \% \mathrm{Sn}+0,3 \% \mathrm{Bi}$ & 2312 & $-1,021$ \\
\hline 5. & $\mathrm{Al}+5 \% \mathrm{Zn}+0,25 \% \mathrm{Sn}+0,4 \% \mathrm{Bi}$ & 2197 & $-1,003$ \\
\hline 6. & $\mathrm{Al}+5 \% \mathrm{Zn}+0,25 \% \mathrm{Sn}+0,5 \% \mathrm{Bi}$ & 2110 & $-0,999$ \\
\hline 7. & $\mathrm{Al}+5 \% \mathrm{Zn}+0,25 \% \mathrm{Sn}$ & 2254 & $-1,018$ \\
\hline
\end{tabular}

There are different views on the role of tin and assumed that creation of additional cation vacancies byentering tin as quadravalent $\mathrm{Sn}^{4+}$ is responsible for improving the cathodic protection properties. However, no experimental evidence is available on the subject. Recently, the mechanism involved in increasing the anode efficiency before and after heat treatment* of tin activated aluminium alloy anodes was explained on the basis of surface free energy [13] which was evaluated by determining the Young's Modulus and atomic spacing of the anode materials experimentally. It was clearly shown that decrease in surface free energy with the addition of tin to $(\mathrm{Al}+5 \% \mathrm{Zn})$ and after the heat treatment is the principal reason for increasing the cathodic protection properties of these alloys.

- Anodes made of aluminium alloy activated with bismuth, obtained by addition from $0,005 \%$ to $1 \%$ of Bi to the basic material, are increasing the effectiveness of protection of the (Al + 5\% Zn) from 65 to $71 \%$. An addition of bismuth to the activated with tin anode made of aluminium has supremacy over patented by authors of [14] method, because effectiveness of protection in sea water provided by the anode ( $\mathrm{Al}+5 \% \mathrm{Zn}+0,2 \% \mathrm{Bi}$ ) has increased to the $83 \%$ by addition of $2 \%$ of magnesium [15]. A reported expansion of an aluminium network and improvement of a crystallite after adding $2 \%$ of magnesium are factors responsible for effectiveness increase.

Properties of bismuth activating the anodes made of aluminium alloy are presented in Table 3.

Table 3 Characteristics of Bi activated aluminium alloy anodes [12] Tablica 3. Karakteristike anoda legure aluminija aktiviranih bizmutom [12]

\begin{tabular}{|c|l|c|c|}
\hline No. & \multicolumn{1}{|c|}{ Composition } & $\begin{array}{c}\text { Anode } \\
\text { capacity } \\
\mathrm{A}-\mathrm{h} / \mathrm{Kg}\end{array}$ & $\begin{array}{c}\text { Closed Circuit } \\
\text { Potential [V] } \\
\mathrm{Ag} / \mathrm{AgCl}\end{array}$ \\
\hline 1. & $\mathrm{Al}+5 \% \mathrm{Zn}+0,05 \% \mathrm{Bi}$ & 2052 & $-0,998$ \\
\hline 2. & $\mathrm{Al}+5 \% \mathrm{Zn}+0,1 \% \mathrm{Bi}$ & 2139 & $-1,002$ \\
\hline 3. & $\mathrm{Al}+5 \% \mathrm{Zn}+0,15 \% \mathrm{Bi}$ & 2197 & $-1,007$ \\
\hline 4. & $\mathrm{Al}+5 \% \mathrm{Zn}+0,2 \% \mathrm{Bi}$ & 2312 & $-1,021$ \\
\hline 5. & $\mathrm{Al}+5 \% \mathrm{Zn}+0,25 \% \mathrm{Bi}$ & 2197 & $-1,003$ \\
\hline 6. & $\mathrm{Al}+5 \% \mathrm{Zn}+0,2 \% \mathrm{Bi}+1 \% \mathrm{Mg}$ & 2110 & $-0,999$ \\
\hline 7. & $\mathrm{Al}+5 \% \mathrm{Zn}+0,2 \% \mathrm{Bi}+2 \% \mathrm{Mg}$ & 2254 & $-1,018$ \\
\hline 8. & $\mathrm{Al}+5 \% \mathrm{Zn}+0,2 \% \mathrm{Bi}+3 \% \mathrm{Mg}$ & 2110 & $-0,999$ \\
\hline 9. & $\mathrm{Al}+5 \% \mathrm{Zn}+0,2 \% \mathrm{Bi}+4 \% \mathrm{Mg}$ & 2254 & $-1,018$ \\
\hline & & & \\
\hline
\end{tabular}

Closed Circuit Potential refers to the potential of an electrode attached to a circuit, in this case sacrificial anode during its operation.

- Indium activated aluminium alloy anodes of ( $\mathrm{Al}+5 \% \mathrm{Zn}$ $+0,03 \%$ In) composition have an efficiency of $80 \%$ [16]. These anodes do not require any heat treatment, no reported pollution problem, exhibits maximum efficiency and shows excellent performance in seawater. Once indium is dissolved, it is immediately reduced at localized sites and thus promotes activation. It is important to note that the presence of chloride ions in solution is a must for indium to activate aluminum [17-21]. The reduced indium ions produce a highly polarizing condition, which promote chloride migration and adsorption, thereby enhancing aluminium dissolution by forming complex chlorides. Reboul has proposed a three step mechanism for the activation of the aluminium by indium [18] and mercury [22].

Effectiveness of anode was improved to $90 \%$ by addition of $2 \%$ of magnesium [23] to ( $\mathrm{Al}+5 \% \mathrm{Zn}+0,03 \% \mathrm{In})$. Authors of [24] confirmed that addition of magnesium to ( $\mathrm{Al}+5 \% \mathrm{Zn}$ $+0,03 \% \mathrm{In}$ ) is helpful in improving the properties of cathodic protection. Homogenization of ( $\mathrm{Al}+5 \% \mathrm{Zn}+0,03 \% \mathrm{In})$ and (Al $+5 \% \mathrm{Zn}+0,03 \% \mathrm{In}+2 \% \mathrm{Mg}$ ) is showing an improved activity of anode. Homogenization of ( $\mathrm{Al}+5 \% \mathrm{Zn}+0,03 \% \mathrm{In}+2 \%$ $\mathrm{Mg}$ ) in effect of water quenching has improved Ecorr and the corrosive current has come up with anodes made of cast iron and cooled by furnace [12]. $\mathrm{E}_{\text {corr }}$ is the mixed potential resulting from established equilibrium between anodic and cathodic reactions upon exposure in the electrolyte.

The metallurgical aspects were studied in detail and it was experimentally [25] shown that decrease in surface free energy after the addition of zinc, indium and $2 \%$ of magnesium is the reason to improve the cathodic protection properties of pure aluminum, $(\mathrm{Al}+5 \% \mathrm{Zn})$ and $(\mathrm{Al}+5 \% \mathrm{Zn}+0,03 \% \mathrm{In})$.

It is an innovative method, as well in evaluating the sacrificial anode materials for cathodic protection purpose. The Young's Modulus, atomic spacing and surface free energy of indium activated aluminium alloy anodes are tabulated in Table 4.

Table 4 Properties of indium activated aluminium alloy anodes [12] Tablica 4. Svojstva anoda legure aluminija aktiviranih indijem [12]

\begin{tabular}{|c|l|c|c|c|}
\hline No. & \multicolumn{1}{|c|}{ Composition } & $\begin{array}{c}\text { Atomic } \\
\text { spacing } \\
{[\mathrm{nm}]}\end{array}$ & $\begin{array}{c}\text { Young's } \\
\text { modulus } \\
{[\mathrm{GNm}]}\end{array}$ & $\begin{array}{c}\text { Anode } \\
\text { capacity } \\
\text { A-h/Kg }\end{array}$ \\
\hline 1. & Pure aluminium & 0,4048 & 62,45 & - \\
\hline 2. & $\mathrm{Al}+5 \% \mathrm{Zn}$ & 0,4023 & 60,68 & - \\
\hline 3. & $\mathrm{Al}+5 \% \mathrm{Zn}+0,03 \% \mathrm{ln}$ & 0,4038 & 56,26 & 2110 \\
\hline 4. & $\mathrm{Al}+5 \% \mathrm{Zn}+0,03 \% \mathrm{ln}+1 \% \mathrm{Mg}$ & 0,4036 & 53,75 & 2119 \\
\hline 5. & $\mathrm{Al}+5 \% \mathrm{Zn}+0,03 \% \mathrm{In}+2 \% \mathrm{Mg}$ & 0,4032 & 52,37 & 2348 \\
\hline 6. & $\mathrm{Al}+5 \% \mathrm{Zn}+0,03 \% \mathrm{In}+3 \% \mathrm{Mg}$ & 0,4047 & 59,26 & 2066 \\
\hline 7. & $\mathrm{Al}+5 \% \mathrm{Zn}+0,03 \% \mathrm{ln}+4 \% \mathrm{Mg}$ & 0,4053 & 64,69 & 1811 \\
\hline
\end{tabular}

Developed anodes are working properly in highly conductive media, such as sea water, but they cannot provide protection while vessel is sailing on low conductive waters. Gurappa [26] developed a hanging anode with addition of a little amount of bismuth to ( $\mathrm{Al}+5 \% \mathrm{Zn}+0,03 \% \mathrm{In}$ ), showing that it will be an alternative for the hanging anode made of magnesium alloy, because of the modern current flow and an effective way of avoiding the problems of overload protection, which was observed in the hanging anodes made of aluminium alloy. 
Atpresent, thefollowingaluminiumanodesareavailableinsale: AAl $(Z n=4-6 \%, I n=0,01-0,03 \%$, rest $-A I), A A l 3(Z n=2-6 \%, M g=0,5-$ $2,5 \%, \mathrm{Si}=0,08 \%, \ln =0,02-0,05 \%$, rest $-\mathrm{Al})$. Their electrochemical potential in regard to $\mathrm{Ag} / \mathrm{AgCl}$ oscillates between 1100 to $1500 \mathrm{mV}$ at the rate of material decrement between $3,4-3,6 \mathrm{~kg} /$ $A^{*}$ r, with current efficiency $2450-2580 A^{*} \mathrm{~kg} / \mathrm{h}$ [26].

\section{DETERMINATION OF ELECTROCHEMICAL POTENTIAL ON MICROSTRUCTURE OF 7020M ALLOY / Određivanje elektrokemijskog potencijala na mikrostrukturi legure 7020M}

\subsection{Own research / Istraživanje}

\subsubsection{Tested material / Testirani materijal}

In order to determine corrosion resistance and stationary potential of $7020 \mathrm{M}$ alloy, local electrochemical investigations were performed on micro-regions of the alloy with the following chemical composition:

$\mathrm{Zn}=5,13 \% ; \mathrm{Mg}=1,9 \% ; \mathrm{Cr}=0,16 \%, \mathrm{Zr}=0,17 \% ; \mathrm{Ti}=0,071 ; \mathrm{Fe}==0,27 \%$;

$\mathrm{Si}=0,15 \% ; \mathrm{Cu}=0,08 \% ; \mathrm{Mn}=0,057 \% ; \mathrm{Ni}=0,006 \%$; A-rest for $\mathrm{T}_{622}$ - heat treatment.

\subsection{Local electrochemical behaviour of aluminium alloy / Lokalno elektrokemijsko ponašanje legure aluminija}

Local electrochemical investigations were carried out using local microcell technique employing microcapillaries. The experimental set-up employed to local polarization examinations is presented in Fig. 2. The electrochemical cell contains reference electrode, counter electrode and microcapillary. Local electrochemical investigations utilized the microcapillaries of $60-80 \mu \mathrm{m}$ diameter. Linear voltamperometry and corrosion potential measurements were performed in 3,5\% (by weight) sodium chloride solution. The polarization curves were collected for the potential scan rate equal $1 \mathrm{~V} / \mathrm{min}$. Local polarization curves were recorded at locations on the matrix and on the phases.

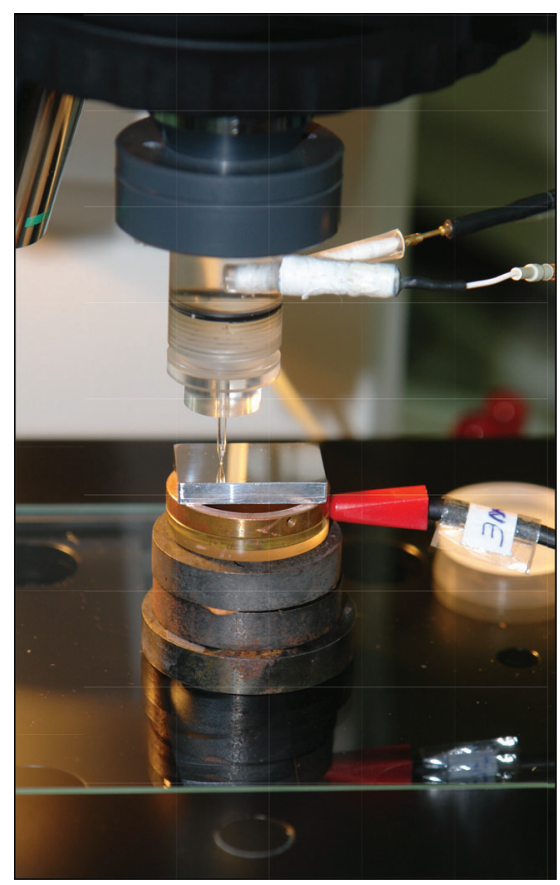

Figure 2 Experimental set-up for local electrochemical measurements (Electrochemical Microcell Technique).

Slika 2. Priprema eksperimenta za lokalna elektrokemijska mjerenja (elektrokemijska Microcell tehnika).

\subsection{Results and discussion / Rezultati i rasprava}

4.3.1. Microstructure of 7020M (507) alloy for the thickness $\mathrm{g}=6$ and $12 \mathrm{~mm}$ after mechanical polishing / Mikrostruktura legure $7020 \mathrm{M}$ debljine $g=6$ i $12 \mathrm{~mm}$ nakon mehaničkog poliranja Fig. 3 and 4 present microstructure of investigated 7020M alloy. The images were collected using scanning electron microscope (SEM). Chemical composition analysis was performed at the locations marked in red. SEM investigations revealed that the alloys contained intermetallic phases comprised mainly of aluminium, magnesium, iron and zinc. Moreover, oxide phases, being a mixture of aluminium, magnesium, silicone and zinc oxides, are also present (dark regions, Fig. 3 and 4). Chemical composition of the micro-regions containing phases, oxides or matrix of particular alloys is provided in Tables 5-6. Presence of given phases has substantial influence on corrosion resistance of examined alloys in electrolyte solutions. Difference in electrochemical potentials between particular phases results in formation of local galvanic cells upon contact with electrolyte, which causes alloy corrosion. Particular phases can act as local cathodes or local anodes with respect to the matrix depending on their electrochemical potential.

\subsubsection{Microstructure of $507(6 \mathrm{~mm}), 507(12 \mathrm{~mm})$ alloys after} mechanical polishing / Mikrostruktura legura $507(6 \mathrm{~mm}), 507$ (12mm) nakon mehaničkog poliranja
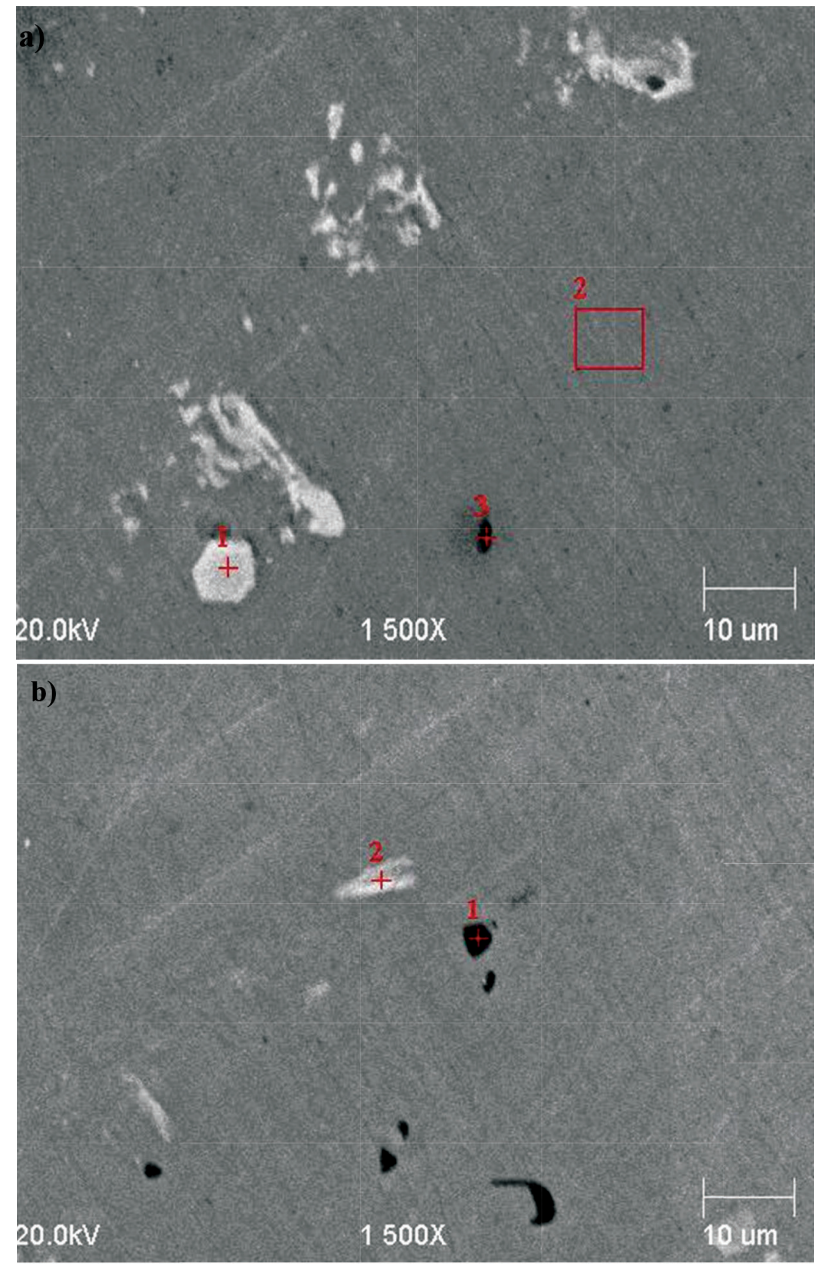

Figure $3(\mathrm{a}, \mathrm{b})$ Microstructure of $7020 \mathrm{M}$ alloy for $\mathrm{g}=6 \mathrm{~mm}$, after mechanical polishing of samples

Slika 3. $(a, b)$ Mikrostruktura legure 7020M za g $=6 \mathrm{~mm}$, nakon mehaničkog poliranja uzoraka 
Table 5 Chemical composition (atomic percent) of selected locations on $7020 \mathrm{M}$ alloy for $\mathrm{g}=6 \mathrm{~mm}$, Fig. 3(a, b).

Tablica 5. Kemijski sastav (omjer atoma) odabranih lokacija na leguri 7020M za g $=6 \mathrm{~mm}$, Slika 3. $(a, b)$.

\begin{tabular}{|c|c|c|c|c|c|}
\hline & $\begin{array}{c}\text { Location } \\
1 \text { (Fig. 3a) } \\
\text { phase }\end{array}$ & $\begin{array}{c}\text { Location } \\
2 \text { (Fig. 3a) } \\
\text { matrix }\end{array}$ & $\begin{array}{c}\text { Location } \\
\text { (Fig. 3a) } \\
\text { oxide }\end{array}$ & $\begin{array}{c}\text { Location } \\
\text { (Fig. 3b) } \\
\text { oxide }\end{array}$ & $\begin{array}{c}\text { Location } \\
\text { (Fig. 3b) } \\
\text { phase }\end{array}$ \\
\hline $\mathrm{O}$ & - & - & 8,9 & 10,17 & 1,4 \\
\hline $\mathrm{Mg}$ & 0,35 & 2,17 & 21,4 & 15,66 & 1,08 \\
\hline $\mathrm{Al}$ & 79,8 & 96,0 & 51,7 & 58,5 & 85,9 \\
\hline $\mathrm{Mn}$ & 0,56 & 0,08 & 0,1 & 0,15 & 0,3 \\
\hline $\mathrm{Cu}$ & 0,42 & 0,01 & 0,72 & 0,30 & 0,4 \\
\hline $\mathrm{Zn}$ & 0,92 & 1,47 & 0,93 & 0,80 & 0,76 \\
\hline $\mathrm{Si}$ & 3,63 & 0,017 & 16,4 & 14,0 & 0,13 \\
\hline $\mathrm{Cr}$ & 0,20 & 0,13 & 0,04 & 0,17 & 0,19 \\
\hline $\mathrm{Fe}$ & 14,0 & 0,093 & 0,2 & 0,21 & 9,8 \\
\hline $\mathrm{Zr}$ & 0,08 & 0,05 & 0,1 & 0,03 & 0,012 \\
\hline
\end{tabular}
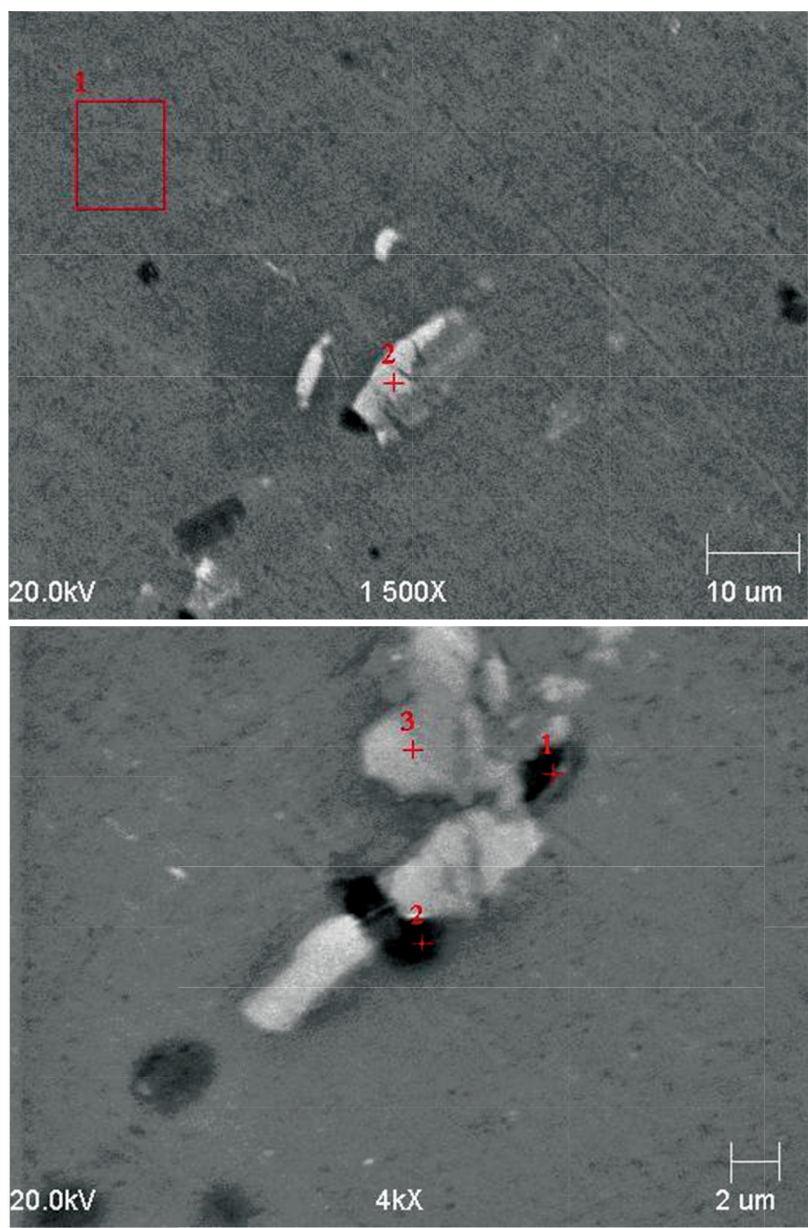

Figure $4(\mathrm{a}, \mathrm{b})$ Microstructure of $7020 \mathrm{M}$ alloy for $\mathrm{g}=12 \mathrm{~mm}$, after mechanical polishing of samples

Slika 4. $(a, b)$ Mikrostruktura legure 7020M za g $=12 \mathrm{~mm}$, nakon mehaničkog poliranja uzoraka
Table 6 Chemical composition (atomic percent) of selected locations on $7020 \mathrm{M}$ alloy for $\mathrm{g}=12 \mathrm{~mm}$, Fig. 4 (a, b).

Tablica 6. Kemijski sastav (omjer atoma) odabranih lokacija na leguri $7020 \mathrm{M}$ za g $=12 \mathrm{~mm}$, Slika $4 .(a, b)$.

\begin{tabular}{|c|c|c|c|c|c|}
\hline & $\begin{array}{c}\text { Location } \\
1 \text { (Fig. 4a) } \\
\text { matrix }\end{array}$ & $\begin{array}{c}\text { Location } \\
\text { 2 (Fig. 4a) } \\
\text { phase }\end{array}$ & $\begin{array}{c}\text { Location 1 } \\
\text { (Fig. 4b) } \\
\text { oxide }\end{array}$ & $\begin{array}{c}\text { Location } \\
\text { 2 (Fig. 4b) } \\
\text { oxide }\end{array}$ & $\begin{array}{c}\text { Location } \\
\text { (Fig. 4b) } \\
\text { phase }\end{array}$ \\
\hline $\mathrm{O}$ & - & - & 19,7 & 17,09 & - \\
\hline $\mathrm{Mg}$ & 2,23 & 0,5 & 1,74 & 3,9 & 0,97 \\
\hline $\mathrm{Al}$ & 95,8 & 82,7 & 72,5 & 69,9 & 88,6 \\
\hline $\mathrm{Mn}$ & 0,099 & 0,35 & 0,156 & 0,17 & 0,205 \\
\hline $\mathrm{Cu}$ & 0,17 & 0,37 & 0,08 & 0,55 & 0,37 \\
\hline $\mathrm{Zn}$ & 1,55 & 1,043 & 1,95 & 3,35 & 0,94 \\
\hline $\mathrm{Si}$ & - & 2,06 & 0,21 & 0,5 & 1,97 \\
\hline $\mathrm{Cr}$ & 0,058 & 0,35 & 0,095 & 0,27 & 0,3 \\
\hline $\mathrm{Fe}$ & - & 12,5 & - & - & 6,5 \\
\hline $\mathrm{Zr}$ & 0,065 & 0,099 & 0,07 & - & 0,13 \\
\hline
\end{tabular}

The polarization curves determined for $7020 \mathrm{M}$ aluminium alloy for $g=6 \mathrm{~mm}$ and $\mathrm{g}=12 \mathrm{~mm}$ show that oxides are the precursors of local corrosion of this alloy. The micro-regions containing oxide phases exhibit the lowest breakthrough potential $\sim-1000 \mathrm{mV}$, Fig. 5 and 6 (green curves). The breakthrough potentials for matrix and phases (red and black curves, Fig. 5 and 6) for both samples of $7020 \mathrm{M}$ alloy are within the range from $-900 \mathrm{mV}$ to $-810 \mathrm{mV}$. The values of corrosion potentials recorded in particular micro-regions of $7020 \mathrm{M}$ alloy for $\mathrm{g}=6 \mathrm{~mm}$ (Fig. 8) are close to or above the breakthrough potentials, which suggests that these phases undergo corrosion in sodium chloride solution. The corrosion potentials for $7020 \mathrm{M}$ alloy for $\mathrm{g}=12 \mathrm{~mm}$, Fig. 8 , are localized in the passive region visible in the LSV (Linear Sweep Voltammetry) curves, Fig. 6. Only intermetallic phases reveal corrosion potential in the active region (above the breakthrough potential). Accordingly, the results show that the sample of $7020 \mathrm{M}$ for $\mathrm{g}=12 \mathrm{~mm}$ possesses slightly better corrosion resistance in sodium chloride solution that the sample of $7020 \mathrm{M}$ for $\mathrm{g}=6 \mathrm{~mm}$.

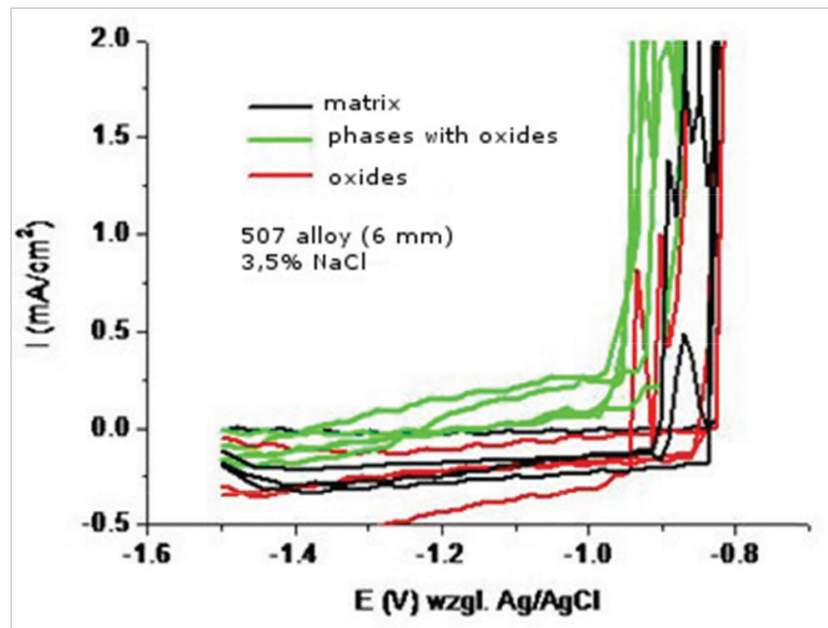

Figure 5 Local polarization curves (LSV) obtained on microregions of $7020 \mathrm{M}$ alloy for $\mathrm{g}=12 \mathrm{~mm}, \mathrm{v}=1 \mathrm{~V} / \mathrm{min}$

Slika 5. Lokalne polarizacijske krivulje (LSV) dobivene na mikropodručjima legure $7020 \mathrm{M} z a \mathrm{~g}=12 \mathrm{~mm}, \mathrm{v}=1 \mathrm{~V} / \mathrm{min}$ 


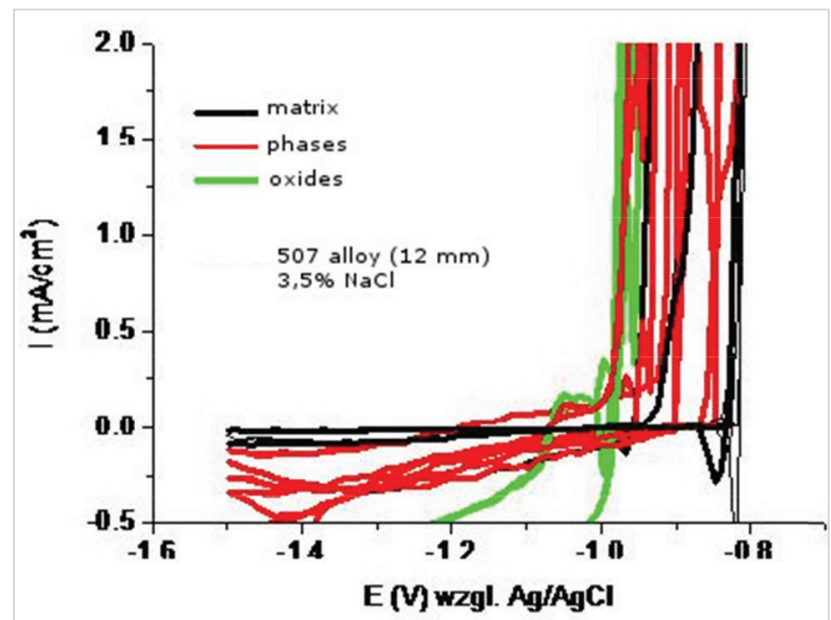

Figure 6 Local polarization curves (LSV) obtained on microregions of $7020 \mathrm{M}$ alloy for $\mathrm{g}=12 \mathrm{~mm}, \mathrm{v}=1 \mathrm{~V} / \mathrm{min}$

Slika 6. Lokalne polarizacijske krivulje (LSV) dobivene na mikropodručjima legure $7020 \mathrm{M} \mathrm{za} g=12 \mathrm{~mm}, \mathrm{v}=1 \mathrm{~V} / \mathrm{min}$

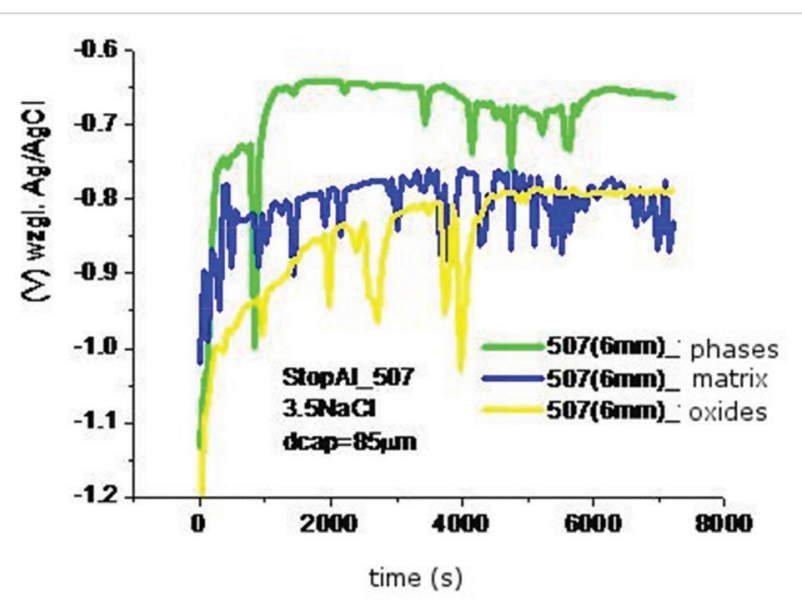

Figure 7 Corrosion potential recorded on micro-regions engulfing matrix and phases of $7020 \mathrm{M}$ alloy for $\mathrm{g}=6 \mathrm{~mm}$

Slika 7. Potencijal za nastanak korozije zabilježen na mikropodručjima koja obuhvaćaju matricu i faze legure $7020 \mathrm{M} \mathrm{za}$ $g=6 \mathrm{~mm}$

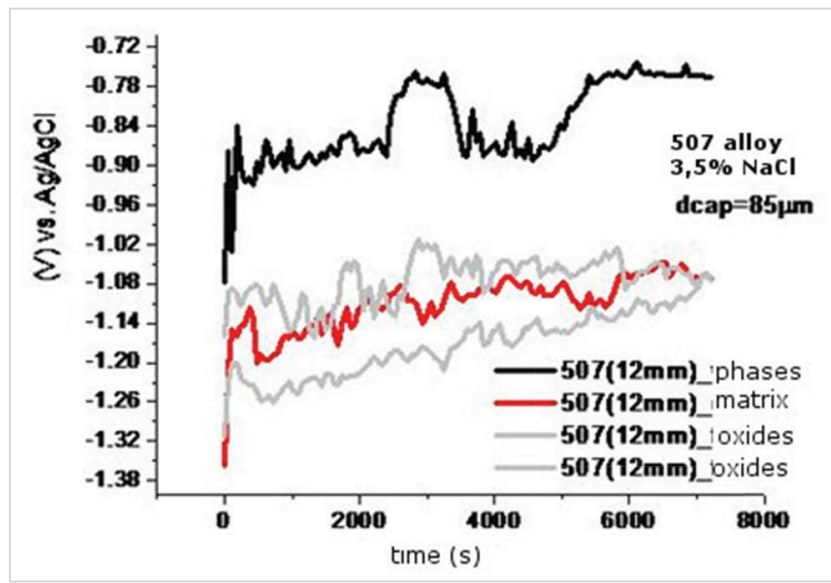

Figure 8 Corrosion potential recorded on micro-regions engulfing matrix and phases of $7020 \mathrm{M}$ alloy for $\mathrm{g}=12 \mathrm{~mm}$

Slika 8. Potencijal za nastanak korozije zabilježen na mikropodručjima koja obuhvaćaju matricu i faze legure $7020 \mathrm{M} \mathrm{za}$ $g=12 \mathrm{~mm}$
Investigated $7020 \mathrm{M}$ alloy for two values of thickness $\mathrm{g}=6$ and $12 \mathrm{~mm}$, marked as 507 , is susceptible to local corrosion in $3,5 \%$ sodium chloride solution. The polarization tests conducted in micro-regions revealed that oxides were the precursors of local corrosion and $7020 \mathrm{M}$ alloy for $\mathrm{g}=12 \mathrm{~mm}$ exhibited slightly superior corrosion resistance than the samples of the same alloy with $\mathrm{g}=6 \mathrm{~mm}$.

Selection of $7020 \mathrm{M}$ alloy for both wall thicknesses as sacrificial anode material must be related to the lowest value of local electrochemical potential of the microstructure. The investigations showed that oxides had the lowest potential ca. $-1000 \mathrm{mV}$. That is why sacrificial anode protection should involve only these materials, the potential of which is below $-1002 \mathrm{mV}$ (see Table 2 and 3). Potential candidates are as follows: $\mathrm{Al}+5 \% \mathrm{Zn}+0,1 \% \mathrm{Bi}, \mathrm{Al}+$ $5 \% Z n+0,15 \% B i, A l+5 \% Z n+0,2 \% B i, A l+5 \% Z n+0,2 \% B i+2 \% M g$ $i \mathrm{Al}+5 \% \mathrm{Zn}+0,2 \% \mathrm{Bi}+4 \% \mathrm{Mg}$ lub Al $+5 \% \mathrm{Zn}+0,25 \% \mathrm{Sn}+0,1 \% B i$ $\mathrm{Al}+5 \% \mathrm{Zn}+0,25 \% \mathrm{Sn}+0,2 \% \mathrm{Bi} ; \mathrm{Al}+5 \% \mathrm{Zn}+0,25 \% \mathrm{Sn}+0,3 \% \mathrm{Bi}$

\section{CONCLUSIONS / Zaključci}

1. Anticorrosive passive protection with use of aluminium and its alloys effectively protects maritime constructional materials from the corrosive influence of the corrosive environment. Oxides of intermetallic compounds of the microstructure of the tested aluminum alloys have a lower electrochemical potential than the general potential of this alloy. This means that the material of sacrificial anodes must have an electrochemical potential lower than the potential of oxides to eliminate pitting corrosion.

2. Low stationary potentials of the newest aluminium sacrificial anodes with zinc, tin, magnesium, indium and bismuth (Table 2-3) provide effective protection against corrosion for all of the constructional materials.

3. Set of epoxy-based protective paint provides better protection from the simultaneous influence of the maritime corrosive environment and tensile stress for the naval aluminum alloys than set of polyvinyl - based paint (Fig.1). Particularly analysis of the results of the researches on stress corrosion of the welded joints of $7020 \mathrm{M}$ alloy leads to the following conclusions:

simultaneously with the increase in the total zinc and magnesium content in the $\mathrm{Al}-\mathrm{Zn}-\mathrm{Mg}$ alloys there is a reduction of their stress corrosion resistance when $3 \%$ solution of $\mathrm{NaCl}$ is used and under the stress of $\sigma=0,8 \mathrm{R}_{0,2}$, during 1500 hours.

the used method of welding and the thickness of the welded sheets of the $7020 \mathrm{M}$ alloy have an influence on the stress corrosion resistance of the welded joints of the examined alloy. Too thin sheets of welded material and the manual welding cause a greater probability of stress corrosion activity.

a proper selection of the protective paint system increases the stress - corrosion resistance ( in conditions of 3\% solution of $\mathrm{NaCl}$, under the stress of $\sigma=0,6 \mathrm{R}_{0,2^{\prime}}$ during 3000 hours) of the welded joints of $7020 \mathrm{M}$ alloy, for the filler metal SPA20.

- in general, the multi-layer epoxy paint system provides more effective stress corrosion protection. It is confirmed not only by the lower number of cracked samples, but also by the $5 \%$ lower $\mathrm{K}_{\mathrm{Rm}}$ and $8 \%$ lower $\mathrm{K}_{\mathrm{A} 5}$ coefficients as compared to the adequate samples protected by polyvinyl paints. 


\section{REFERENCES / Literatura}

[1] "Corrosion Costs and Preventive Strategies in the United States Report". www. corrosioncost.com

[2] Yue, J., Cao, Y. (2015). "Corrosion Prevention by Applied Coatings on Aluminium Alloys in Corrosive Environments". Int. J. Electrochem. Sci., Vol. 10, pp. 5222-5237.

[3] Cudny, K. (1996). Technologia konstrukcji okrętowych ze stopów aluminium. Gdańsk: Wydawnictwo Politechniki Gdańskiej.

[4] Czechowski, M., Zieliński, A., Jurczak, W. (2000). Stress corrosion cracking of same aluminium alloys and their welded joints. Environmental degradation of engineering materials Inżynieria Materiałowa.

[5] Soboń, D., Kaczmarczyk, M., Makrenek, M., Sienicki, J., Żurawski, W. (2018). "Corrosion properties of cold sprayed aluminum coatings". Przegląd spawalnictwa, Vol. 90, No. 12, pp. 4-7.https://doi.org/10.26628/wtr.v90i12.982

[6] Karliński, W., Szachowski, W. (1999). Testing of material resistance on effect of stress corrosion cracking.

[7] Miszczyk, A., Schauer, T. (2005). "Electrochemical approach to evaluate the interlayer adhesion of organic coatings". Progress in Organic Coatings, Vol. 52 , pp. 298-305, 2005.https://doi.org/10.1016/j.porgcoat.2004.09.006

[8] Jurczak, W. "Effectiveness of corrosion protection of the welded joints of AlZn5Mg2CrZr naval alloy with protective paint systems". Polish Journal of Environmental Studies 2006.

[9] Scheiber, C. F., Reding, J. T. (1967). Materials Protection.

[10] Keir, D. S., Pyror, M. J., Sperry, P. R. (1977). Journal of the Electrochemical Society.
[11] Gurrappa, I., Karnik, J. A. (1994). Corrosion Prevision.

[12] Gurrappa, I. (2005). Cathodic protection of ships.

[13] Gurrappa, I. (1993). Corrosion Prevision and Control.

[14] U. S. Patent 1968 No. 3.368958

[15] Kulkarni, A. G., Gurrappa, I. (1991). Bull. Electrochemical.

[16] Sakano, T., Toda, K. (1996). Materials Protection.

[17] Bessone, J. B. (1986). National Seminarian, Brazil.

[18] Reboul, M., Gimenez, P., Rameau, J. (1984). Corrosion.

[19] Breslin, C., Carroll, W. (1993). Corrosion Society.

[20] Carroll, W., Breslin, C. (1992). Corrosion Society.

[21] Reobul, M., Dealatte, M. (1980). Materials Performance.

[22] Kulinarni, A., Grrappa, I. (1993). British Corrosion Journal.

[23] Yue, J., Cao, Y. (2015). "Corrosion Prevention by Applied Coatings on Aluminum Alloys in Corrosive Environments". Int. J. Electrochem. Sci., Vol. 10, pp. 5222-5237.

[24] Lin, J., Shih, H. (1987). Journal of the Electrochemical Society.

[25] Katalog protektorów ochronnych aluminiowych, MakroMor - Cathodic Protection (2018)

[26] Schuman, T. P. “Protective Coatings for Aluminum Alloys", Chapter 20. https:// doi.org/10.1016/B978-0-323-52472-8.00021-6Get rights and content/2019

[27] http://www.ihccorp.com/primary-coatings.html/2019 